\title{
Pengaruh Model Problem Based Learning (PBL) Berbasis Scientific Approach terhadap Hasil Belajar Biologi Siswa Kelas X Di SMA N 2 Banguntapan T.A. 2014 / 2015
}

\author{
DIAN NOVIAR, DWI RENI HASTUTI \\ Pendidikan Biologi UIN Sunan Kalijaga Yogyakarta \\ *email: diannoviar84@yahoo.co.id
}

Manuscript received: 22 Mei 2015 Revision accepted: 30 Juli 2015

\begin{abstract}
Penelitian ini bertujuan untuk (1) mengetahui pengaruh model Problem Based Learning berbasis Scientific Approach terhadap hasil belajar biologi pada ranah kognitif siswa kelas X SMA Negeri 2 Banguntapan T.A 2014/2015, (2) mengetahui pengaruh model Problem Based Learning berbasis Scientific Approach terhadap hasil belajar biologi pada ranah afektif siswa kelas X SMA Negeri 2 Banguntapan T.A 2014/2015, (3) mengetahui pengaruh model Problem Based Learning berbasis Scientific Approach terhadap hasil belajar biologi pada ranah psikomotorik siswa kelas X SMA Negeri 2 Banguntapan T.A 2014/2015. Penelitian ini termasuk jenis penelitian quasi experiment (eksperimen semu) dengan design penelitian yang digunakan adalah Nonequivalent control group design. Populasi penelitian adalah semua siswa kelas $\mathrm{X}$ SMA N 2 Banguntapan. Sampel penelitian terdiri dari dua kelas yang diambil dengan menggunakan teknik purposive sampling dan simple random sampling, yaitu kelas X3 (kelas eksperimen) dan kelas X4 (kelas kontrol). Teknik pengumpulan data menggunakan tes, angket, dan observasi. Analisis data hasil belajar siswa pada ranah kognitif menggunakan One Way Anova, sedangkan untuk hasil belajar pada ranah afektif dan psikomotor menggunakan uji Mann Whitney U. Berdasarkan hasil penelitian dapat disimpulkan bahwa (1) model Problem Based Learning berbasis Scientific Approach secara signifikan meningkatkan hasil belajar biologi pada ranah kognitif siswa dengan ditunjukkan $p$-value sebesar 0,001 < 0,05. (2) model Problem Based Learning berbasis Scientific Approach secara signifikan meningkatkan hasil belajar biologi pada ranah afektif siswa dengan ditunjukkan $p$-value sebesar 0,029 < 0,05. (3) model Problem Based Learning berbasis Scientific Approach secara signifikan meningkatkan hasil belajar biologi pada ranah psikomotor siswa dengan ditunjukkan $p$-value sebesar $0,000<0,05$.
\end{abstract}

Keywords: Model PBL, Scientific Approach, Avertebrata, Hasil Belajar

\section{LATAR BELAKANG}

Saat ini perkembangan IPTEK sangat pesat. Hal tersebut berdampak semakin kompleksnya permasalahan yang dihadapi dunia pendidikan. Salah satu masalah yang dihadapi adalah rendahnya kualitas pendidikan. Berdasarkan data Education For Global Monitoring Report 2012 oleh UNESCO setiap tahunnya menunjukkan bahwa pendidikan Indonesia berada di peringkat ke-64 dari 120 negara, sedangkan menurut data Education Development Index (EDI), pendidikan di Indonesia berada pada peringkat ke-69 dari 127 negara pada tahun 2011 (Harahap, 2013).Selain itu, menurut The Political and Economic Risk Consultancy (PERC) yang merupakan lembaga konsultan dari Hongkong menyatakan kualitas pendidikan di Indonesia sangat rendah, Indonesia berada di peringkat ke12 dari negara-negara di Asia (Syamsuri, 2010: 2).

Salah satu upaya pemerintah dalam meningkatkan kualitas pendidikan di Indonesia adalah mengadakan perbaikan kurikulum. Pada tahun 2006 pemerintah Indonesia memberlakukan Kurikulum Tingkat Satuan Pendidikan (KTSP). Sejalan dengan penerapan KTSP, guru memiliki kebebasan dalam berinovasi dan memilih model pembelajaran yang diterapkan di kelas untuk menciptakan pembelajaran yang berpusat pada siswa serta dapat meningkatkan kualitas pembelajaran khususnya pada pembelajaran biologi.
Pembelajaran biologi yang berpusat pada siswa memberikan kesempatan siswa untuk berpartisipasi aktif dalam pembelajaran sehingga mampu meningkatkan kreativitas dan kompetensi siswa. Pembelajaran biologi yang berpusat pada siswa dimaksudkan untuk melibatkan siswa dalam mengkonstruksi sendiri pengetahuannya sehingga siswa lebih dominan dalam pembelajaran. Hal tersebut dapat mengembangkan pengetahuan, keterampilan dan sikap percaya diri siswa. Selain itu, proses pembelajaran biologi harus berdasarkan data dan fakta ilmiah agar diperoleh suatu pembelajaran yang bermakna (A'la, 2010: 176).

Tujuan pembelajaran biologi yang ingin dicapai dari proses pendidikan adalah hasil belajar biologi siswa yang meliputi ranah kognitif, afektif, dan psikomotor. Ketiga ranah tersebut merupakan satu kesatuan yang tidak dapat dipisahkan. Sementara itu, kegiatan pembelajaran biologi selama ini kurang memberi kesempatan kepada siswa untuk berperan aktif dalam pembelajaran. Peranan guru masih sangat dominan dan kurang optimal dalam menggunakan pendekatan pembelajaran, sehingga membuat siswa kurang aktif dalam pembelajaran dan kualitas belajar siswa menjadi rendah. Kurang aktifnya siswa dalam pembelajaran biologi tersebut akan menyebabkan konsep-konsep biologi tidak bermakna dan selanjutnya tidak dapat dipahami dengan baik (Nurhidayat, 
2011: 3). Hal tersebut menimbulkan permasalahan bagi pihak sekolah.

Permasalahan tersebut selaras dengan hasil observasi dan wawancara di SMA Negeri 2 Banguntapan pada T.A 2014/2015 bahwa pembelajaran biologi yang dilakukan guru di kelas masih didominasi dengan model Direct Instruction, belum menggunakan variasi model pembelajaran lainnya serta kurang memberikan gambaran yang nyata kepada siswa terkait materi yang sedang diajarkan. Hal tersebut mengakibatkan siswa tidak memperhatikan guru dan sibuk dengan temannya sendiri sehingga kelas menjadi gaduh. Selain itu, sebagian besar siswa menganggap biologi sebagai ilmu hafalan yang hanya diperoleh dari buku referensi saja dan tidak berdasarkan proses ilmiah. Hal tersebut berdampak pada hasil belajar siswa yang kurang maksimal, yakni $100 \%$ siswa hasil belajar biologi pada materi Avertebrata belum mencapai Kriteria Ketuntasan Minimal (KKM) sebesar 75 dengan nilai rata-rata yang dicapai siswa sebesar 50,33 pada materi Avertebrata. Selain itu, penilaian yang dilakukan guru hanya dilakukan pada ranah kognitif dan belum menyentuh ranah afektif dan psikomotorik.

Upaya dalam menghadapi permasalahan di atas yaitu dibutuhkan suatu inovasi model pembelajaran yang efektif untuk meningkatkan hasil belajar biologi siswa, sehingga dapat memenuhi KKM. Model pembelajaran yang dapat digunakan adalah model pembelajaran yang menggunakan model Problem Based Learning (PBL). Model pembelajaran Problem Based Learning merupakan salah satu model pembelajaran yang mengarah pada kemampuan berpikir kritis dan mendorong siswa untuk melakukan pemecahan masalah sesuai dengan kehidupan nyata. Problem Based Learning dapat merangsang siswa untuk aktif dalam pembelajaran dan menghasilkan sebuah produk atau karya. Model Problem Based Learning diharapkan dapat meningkatkan hasil belajar siswa terhadap konsep biologi, karena siswa mengkonstruksi sendiri pengetahuan yang siswa dapatkan.

Proses pembelajaran biologi yang menggunakan model Problem Based Learning dapat didukung dengan suatu pendekatan pembelajaran yang tepat, salah satunya dengan pendekatan saintifik (Scientific Approach). Pendekatan saintifik merupakan suatu pendekatan atau mekanisme untuk memperoleh pengetahuan yang berdasarkan pada suatu metode ilmiah dan terhindar dari nilai-nilai non ilmiah. Oleh karena itu, pendekatan ilmiah harus memuat rangkaian data dan fakta melalui observasi dan eksperimen (Kemendikbud, 2013: 141). Dengan demikian siswa benarbenar diberi kesempatan untuk mengalami sendiri, mengikuti suatu proses, mengamati suatu obyek, menganalisis, membuktikan dan menarik kesimpulan sendiri mengenai suatu keadaan. Oleh karena itu, model Problem Based Learning berbasis Scientific Approach diharapkan dapat meningkatkan hasil belajar siswa terhadap konsep biologi.

Hasil penelitian Arnyana (2007) menunjukkan bahwa Problem Based Learning mampu meningkatkan keefektifan pembelajaran sehingga dapat meningkatkan kemampuan berpikir kritis siswa pada pelajaran biologi. Hasil penelitian Hidayati (2014), menunjukkan bahwa pembelajaran dengan menggunakan pendekatan saintifik dapat meningkatkan hasil belajar siswa dan membuat suasana pembelajaran lebih kondusif. Selain itu, dengan menggunakan pendekatan ilmiah proses pembelajaran akan terjadi keseimbangan pada ranah kognitif, afektif, dan psikomotorik. Berdasarkan uraian yang telah dikemukakan di atas, maka penulis tertarik untuk melakukan penelitian dengan judul penelitian "Pengaruh Model Problem Based Learning Berbasis Scientific Approach Terhadap Hasil Belajar Biologi Siswa Kelas X Di SMA N 2 Banguntapan T.A 2014/2015”.

\section{METODE}

Jenis penelitian yang digunakan dalam penelitian ini adalah kuasi eksperimen. Populasi penelitian adalah seluruh siswa kelas X SMA N 2 Banguntapan T.A 2014/2015 sebanyak 4 kelas. Sampel penelitian terdiri dari dua kelas yaitu kelas $\mathrm{X} 3$ dan $\mathrm{X} 4$ yang diambil secara purposive sampling dan simple random sampling. Kelas X3 sebagai kelas eksperimen yang diberi perlakuan menggunakan Model Problem Based Learning (PBL) berbasis Scientific Approach dan kelas X4 sebagai kelas kontrol yang diberi perlakuan menggunakan Model Direct Instruction. Teknik pengumpulan data menggunakan metode tes untuk memperoleh data hasil belajar kognitif, metode angket untuk mendapatkan hasil belajar afektif, dan metode observasi untuk mendapatkan hasil belajar psikomotor.

Uji hipotesis untuk data hasil belajar kognitif menggunakan One Way Anova, sedangkan untuk data hasil belajar afektif dan psikomotor diuji menggunakan uji Mann Whitney $U$. uji statistik dilakukan pada taraf signifikansi $5 \%$. Dalam penelitian ini persyaratan yang harus dipenuhi terlebih dahulu, sebelum melakukan uji hipotesis adalah data harus melalui uji normalitas dan uji homogenitas varians.

\section{HASIL DAN PEMBAHASAN}

Data dalam penelitian ini meliputi data hasil belajar kognitif, afektif dan psikomotor. Data tersebut diperoleh dari hasil tes, angket, dan observasi pada siswa kelas X3 yang berjumlah 32 siswa dan kelas $\mathrm{X} 4$ yang berjumlah 32 siswa. Pada penelitian ini kelas X3 sebagai kelas eksperimen dan kelas X4 sebagai kelas kontrol. Berdasarkan penelitian yang dilakukan di SMA N 2 Banguntapan, diperoleh hasil sebagai berikut:

Tabel 1. Deskripsi Data Nilai Hasil Belajar Kognitif Siswa

\begin{tabular}{ccccc}
\hline Kelas & $\begin{array}{c}\text { Jumlah } \\
\text { Siswa }\end{array}$ & Mean & Maks & Min \\
\hline Kontrol & 32 & 64,34 & 80 & 44 \\
Eksperimen & 32 & 71,50 & 84 & 57 \\
\hline
\end{tabular}

Berdasarkan Tabel 1, secara keseluruhan dapat disimpulkan bahwa rata-rata nilai kelas eksprimen lebih tinggi dibandingkan kelas kontrol 
Tabel 2. Distribusi Kategori Nilai Kognitif Siswa

\begin{tabular}{ccccc}
\hline \multirow{2}{*}{ Kategori } & \multicolumn{2}{c}{ Kelas Kontrol } & \multicolumn{2}{c}{$\begin{array}{c}\text { Kelas } \\
\text { Eksperimen }\end{array}$} \\
\cline { 2 - 5 } & $\mathbf{N}$ & $\begin{array}{c}\text { Persentase } \\
(\mathbf{\%})\end{array}$ & $\mathbf{N}$ & $\begin{array}{c}\text { Persentase } \\
(\boldsymbol{\%})\end{array}$ \\
\hline Sangat baik & 1 & 3 & 8 & 25 \\
Baik & 16 & 50 & 17 & 53 \\
Cukup & 11 & 35 & 7 & 22 \\
Kurang & 3 & 9 & 0 & 0 \\
Sangat Kurang & 1 & 3 & 0 & 0 \\
\hline Jumlah & $\mathbf{3 2}$ & $\mathbf{1 0 0}$ & $\mathbf{3 2}$ & $\mathbf{1 0 0}$ \\
\hline
\end{tabular}

Berdasarkan Tabel 2, pada kelas kontrol terdapat 3\% siswa yang memiliki nilai dengan kategori sangat baik dan $25 \%$ siswa pada kelas eksperimen yang memiliki nilai dengan kategori sangat baik. Dapat disimpulkan bahwa nilai siswa kelas eksperimen lebih baik dibandingkan kelasa kontrol.

Tabel 3. Persentase Ketuntasan Hasil Belajar Siswa

\begin{tabular}{ccccc}
\hline \multirow{2}{*}{ Ketuntasan } & \multicolumn{2}{c}{ Kontrol } & \multicolumn{2}{c}{ Eksperimen } \\
\cline { 2 - 5 } & $\mathbf{N}$ & Persentase & N & Persentase \\
\hline Tuntas & 6 & 18,75 & 16 & 50 \\
Tidak Tuntas & 12 & 81,25 & 16 & 50 \\
\hline Jumlah & $\mathbf{3 2}$ & $\mathbf{1 0 0}$ & $\mathbf{3 2}$ & $\mathbf{1 0 0}$ \\
\hline
\end{tabular}

Berdasakan Tabel 3, hanya 18,75\% siswa kelas kontrol yang mencapai ketuntasan hasil belajar, sedangkan pada kelas eksperimen siswa yang mencapai ketuntasan hasil belajar mencapai 50\%. Dapat disimpulkan bahwa kelas eksperimen memiliki persentase ketuntasan hasil belajar yang lebih tinggi dibandingkan kelas kontrol.

Tabel 4. Deskripsi data Nilai Hasil Belajar Afektif Siswa

\begin{tabular}{ccccc}
\hline Kelas & $\begin{array}{c}\text { Jumlah } \\
\text { Siswa }\end{array}$ & Mean & Maks & Min \\
\hline Kontrol & 32 & 73,87 & 97 & 61 \\
Eksperimen & 32 & 78,78 & 93 & 63 \\
\hline
\end{tabular}

Pada Tabel 4 menunjukkan bahwa nilai rata-rata afektif kelas eksperimen lebih baik dibandingkan dengan kelas kontrol, sehingga dapat disimpulakan bahwa terdapat perbedaan yang signifikan hasil belajar afektif siswa pada kedua kelas tersebut.

Tabel 5. Deskripsi data Nilai Hasil Belajar Psikomotor Siswa

\begin{tabular}{ccccc}
\hline Kelas & $\begin{array}{c}\text { Jumlah } \\
\text { Siswa }\end{array}$ & Mean & Maks & Min \\
\hline Kontrol & 32 & 52,46 & 59 & 45 \\
Eksperimen & 32 & 57,25 & 64 & 50 \\
\hline
\end{tabular}

Pada Tabel 5 menunjukkan bahwa nilai rata-rata psikomotor kelas eksperimen lebih baik dibandingkan dengan kelas kontrol, sehingga dapat disimpulakan bahwa terdapat perbedaan yang signifikan hasil belajar psikomotor siswa pada kedua kelas tersebut.
Uji hipotesis untuk data hasil belajar kognitif menggunakan One Way Anova, sedangkan untuk data hasil belajar afektif dan psikomotor diuji menggunakan uji Mann Whitney $U$. pengujian hipotesis menggunakan SPSS for Windows versi 16.0. Uji statistik dilakukan pada taraf signifikansi 5\%. Jika $p$-value $<0,05$, maka Ho ditolak yang berarti terdapat perbedaan atau pengaruh, sedangkan jika $p$ value $>0,05$, maka Ho diterima yang berarti tidak terdapat perbedaan atau pengaruh. Adapun ringkasan hasil uji hipotesis diperlihatkan pada Tabel 6.

Tabel 6. Hasil Uji Hipotesis Hasil Belajar Kognitif, Afektif, dan Psikomotor

\begin{tabular}{ccc}
\hline Hipotesis & Hasil Belajar & Sig. \\
\hline 1 & Kognitif & 0,001 \\
2 & Afektif & 0,029 \\
3 & Psikomotror & 0,000 \\
\hline
\end{tabular}

Berdasarkan Tabel 6, dapat disimpulkan pengujian hipotesis pada ranah kognitif, afektif, dan psikomotor sebagai berikut:

\section{Hasil Belajar Kognitif}

Berdasarkan keputusan uji hipotesis, didapatkan bahwa hipotesis nol ditolak, sehingga dapat disimpulkan bahwa model Problem Based Learning berbasis Scientific Approach secara signifikan meningkatkan hasil belajar biologi pada ranah kognitif siswa kelas X Di SMA Negeri 2 Banguntapan T.A 2014/2015.

Penggunaan model Problem Based Learning berbasis Scientific Approach membuat hasil belajar ranah kognitif kelas eksperimen lebih tinggi daripada kelas kontrol. Model Problem Based Learning berbasis Scientific Approach memungkinkan siswa memperoleh pengetahuan dari hasil penemuan sendiri dan bukan hasil mengingatingat (Irwandi, 2012: 33). Pembelajaran dengan menggunakan model Problem Based Learning berbasis Scientific Approach lebih mengutamakan proses dan keterampilan berpikir mulai dari menganalisis masalah hingga mengkomunikasikan (Swarabama, 2013: 7).

Dalam proses belajar tersebut siswa terlibat dalam kegiatan seperti mengobservasi, mengumpulkan data, dan menganalisis masalah serta mampu berpikir kritis. Dengan penggunaan model tersebut siswa dapat mengembangkan kemampuan berpikir dalam penyelesaian masalah dan keterampilan intelektual.

Berdasarkan kerucut pengalaman Dale (Indriana, 2011: 24), pengetahuan akan semakin abstrak apabila pesan hanya disampaikan melalui kata verbal. Akibatnya, siswa hanya akan memahami suatu pengetahuan dalam bentuk kata tanpa mengerti dan memahami makna yang terkandung dalam pengetahuan tersebut. Hal ini membuat siswa harus memiliki pengalaman yang konkret dalam memperoleh suatu pengetahuan.Penggunaan model Problem Based Learning berbasis Scientific Approach membuat siswa terlibat aktif dalam proses pembelajaran dan memperoleh pengetahuan secara konkret. Hal tersebut 
dapat meningkatkan aktivitas pembelajaran siswa dan siswa menjadi lebih ingat terhadap materi pelajaran yang telah diberikan (Sanjaya, 2007:220). Hasil belajar ranah kognitif kelas kontrol lebih rendah daripada kelas eksperimen disebabkan kelas kontrol hanya menggunakan model Direct Instruction. Model tersebut membuat siswa hanya mencatat dan mendengarkan penjelasan dari guru, sehingga siswa hanya memperoleh pengetahuan dengan cara mengingat-ingat dan bukan melalui suatu proses penemuan. Hal tersebut mengakibatkan siswa sulit untuk mencapai keberhasilan belajar secara optimal.

Perbedaan rata-rata hasil belajar kognitif disebabkan perbedaan aktivitas belajar siswa pada kedua kelas tersebut. Pada kelas kontrol, aktivitas siswa relatif rendah karena siswa kurang aktif dalam pembelajaran. Siswa hanya mendengarkan penjelasan dari guru, mencatat, dan diskusi soal. Pada sintaks pertama model Direct Instruction guru menyampaikan tujuan pelajaran, latar belakang pembelajaran, pentingnya pembelajaran, dan mempersiapkan siswa. Pada tahap ini siswa mendengarkan apa yang diinstruksikan oleh guru. Sintaks kedua model Direct Instruction adalah mendemonstrasikan keterampilan. Tahap ini guru mendemonstrasikan ketrampilan dengan benar atau memberi informasi tahap demi tahap dan siswa mendengarkan semua informasi yang diberikan dari guru.

Sintaks ketiga model Direct Instruction adalah guru memberikan latihan terbimbing kepada siswa yang diikuti sintaks keempat yaitu mengecek pemahaman dan memberikan umpan balik kepada siswa. Pada tahap ini terjadi interaksi dua arah antara guru dan siswa. Sintaks kelima model Direct Instruction adalah memberikan kesempatan untuk pelatihan lanjut dan penerapan. Pada tahap ini guru memberikan pelatihan lanjutan secara mandiri. Hal ini dimaksudkan agar siswa lebih paham terhadap materi yang telah diajarkan.

Berdasarkan sintaks model Direct Instruction yang telah diterapkan pada pembelajaran di kelas kontrol tersebut, dapat diketahui bahwa siswa memiliki aktivitas belajar yang rendah. Siswa yang memiliki aktivitas belajar yang rendah, dapat berakibat pada keinginan untuk belajar yang rendah pula. Hal tersebut akan berdampak pada hasil belajar yang kurang maksimal (Nurbaiti, 2012: 15).

Pada pembelajaran menggunakan model Problem Based Learning berbasis Scientific Approach, siswa berperan aktif dalam pembelajaran dengan sintaks yang jelas yaitu mulai dari mengorientasikan siswa terhadap masalah sampai pada menganalisa masalah yang ada. Setiap sintaks dalam pembelajaran tersebut terdapat kegiatan-kegiatan yang berbasis Scientific Approach mulai dari mengamati sampai mengkomunikasikan. Sintaks pertama dan kedua pada model Problem Based Learning terdapat kegiatan mengamati. Kegiatan mengamati tersebut membuka kesempatan siswa secara luas untuk melakukan pengamatan terkait hal-hal penting dari suatu benda atau objek. Hal tersebut sangat bermanfaat bagi pemenuhan rasa ingin tahu siswa (Machin, 2014: 31). Pada sintaks ketiga model Problem Based Learning terdapat kegiatan menanya. Kegiatan menanya merupakan kegiatan mengajukan pertanyaan tentang informasi yang tidak dipahami. Kegiatan tersebut membuka kesempatan secara luas kepada siswa untuk bertanya mengenai apa yang sudah diamati pada kegiatan mengamati sebelumnya. Kegiatan ini sangat bermanfaat untuk mengembangkan kreativitas, rasa ingin tahu dan kemampuan merumuskan pertanyaan (Fauziah, 2013: 167).

Sintaks keempat pada model Problem Based Learning terdapat kegiatan mengumpulkan data dan mengasosiasikan. Pada kegiatan ini, siswa berusaha mengumpulkan data dari berbagai sumber dan berusaha untuk menemukan keterkaitan antara informasi yang sudah diperoleh.kegiatan mengumpulkan data dan mengasosiasikan ini sangat bermanfaat untuk mengembangkan kemampuan berpikir induktif dan deduktif siswa untuk membuat kesimpulan (Machin, 2014: 32). Pada sintaks kelima model Problem Based Learning terdapat kegiatan mengkomunikasikan. Pada kegiatan ini siswa adalah menyampaikan hasil pengamatan dan kesimpulan berdasarkan hasil analisis secara lisan, tertulis atau dengan media lainnya. Kegiatan mengkomunikasikan tersebut sangat bermanfaat untuk mengembangkan kemampuan berkomunikasi siswa (Fauziah, 2013: 168).

Berdasarkan kegiatan-kegiatan tersebut dapat diketahui bahwa siswa memiliki aktivitas belajar yang tinggi karena siswa berperan aktif dalam kegiatan pembelajaran. Siswa yang berperan aktif dalam pembelajaran akan sangat berpengaruh terhadap tingginya hasil belajar siswa (Nurbaiti, 2012: 16). Tingginya hasil belajar tersebut dapat dilihat dari hasil tes formatif dengan kriteria ketuntasan minimal (KKM) yang sudah ditentukan. Berdasarkan persentase jumlah siswa yang memenuhi KKM, kelas eksperimen memiliki persentase ketuntasan yang lebih banyak dibandingkan dengan kelas kontrol. Oleh karena itu, hasil uji hipotesis hasil belajar siswa menunjukkan bahwa terdapat perbedaan signifikan hasil belajar antara kelas eksperimen dan kelas kontrol. Dengan demikian dapat dinyatakan bahwa model Problem Based Learning berbasis Scientific Approach berpengaruh terhadap hasil belajar biologi pada ranahkognitif siswa kelas X SMA Negeri 2 Banguntapan T.A 2014/2015.

Hasil penelitian ini sesuai dengan penelitian Fauziah (2013: 177), yang menyatakan pembelajaran saintifik berorientasi pembelajaran berbasis masalah dapat meningkatkan kemampuan siswa baik hard skill maupun soft skill. Selain itu, penelitian yang dilakukan oleh Machin (2014: 35) menyatakan bahwa pembelajaran yang berbasis Scientific Approach berpengaruh positif terhadap hasil belajar kognitif siswa dan membuat hasil belajar siswa telah mencapai ketuntasan klasikal yang ditetapkan. Penggunaan model Problem Based Learning berbasis Scientific Approach dimaksudkan agar diperoleh suatu pembelajaran yang konkret dan bermakna melalui proses penerimaan atau penemuan. Model dan pendekatan pembelajaran tersebut akan membuat siswa menghubungkan atau mengaitkan informasi yang baru 
mereka dapat dengan pengetahuan yang telah dimilikinya (Wilis, 1989:110).

\section{Hasil Belajar Afektif}

Berdasarkan keputusan uji hipotesis, didapatkan bahwa hipotesis nol ditolak, sehingga dapat disimpulkan bahwa model Problem Based Learning berbasis Scientific Approach secara signifikan meningkatkan hasil belajar biologi pada ranah afektif siswa kelas X Di SMA Negeri 2 Banguntapan T.A 2014/2015.

Penggunaan model Problem Based Learning berbasis Scientific Approach membuat hasil belajar ranah afektif kelas eksperimen lebih tinggi daripada kelas kontrol. Hal tersebut disebabkan model Problem Based Learning (PBL) menjadikan siswa sebagai produsen pengetahuan yang membuat siswa memperoleh pengetahuannya berdasarkan penemuan sendiri bersama kelompoknya. Proses pembelajaran tersebut secara tidak langsung dapat membantu siswa mengembangkan sikap berupa komunikasi, penalaran, dan berpikir analitis ketika memecahkan masalah bersama kelompoknya (Bondan, 2011: 4). Model Problem Based Learning (PBL) yang dipadukan dengan Scientific Approach dapat mendorong dan menginspirasi siswa untuk berpikir secara kritis, analitis, dan tepat dalam mengidentifikasi, memahami, memecahkan masalah, dan mengaplikasikan materi pelajaran (Sujarwanta, 2012: 75-76).

Hasil belajar ranah afektif kelas kontrol lebih rendah daripada kelas eksperimen disebabkan kelas kontrol hanya menggunakan model Direct Instruction. Model tersebut kurang memberikan kesempatan kepada siswa untuk lebih aktif dalam pembelajaran. Siswa hanya mencatat dan mendengarkan penjelasan dari guru serta mengerjakan tugas dari guru, sehingga siswa cepat merasa bosan dan tidak tertarik dengan pelajaran. Hal tersebut mengakibatkan keinginan untuk belajar menjadi berkurang, sehingga sulit untuk mencapai keberhasilan belajar secara optimal. Menurut Wahyuni (2009) keinginan untuk belajar yang tinggi dapat dilihat dari beberapa perilaku, salah satunya adalah adanya keterlibatan siswa dalam pembelajaran yang tinggi. Berdasarkan pengamatan di kelas saat penelitian berlangsung, kondisi tersebut tidak ditemukan pada kelas kontrol. Siswa hanya mencatat dan mendengarkan penjelasan dari guru serta mengerjakan tugas dari guru. Siswa kurang aktif untuk bertanya dan menanggapi penjelasan dari guru.

Hasil penelitian ini sesuai dengan penelitian Af'idah (2013: 68), yang menyatakan penerapan Model Problem Based Learning (PBL) dapat mengembangkan keterampilan sikap dan kerja sama dalam berbagai situasi. Selain itu, penelitian yang dilakukan oleh Machin (2014: 32) menyatakan bahwa pembelajaran yang berbasis Scientific Approach akan berorientasi pada penanaman sikap/karakter yang mendorong siswa untuk melakukan proses afeksi mulai dari menerima, menjalankan, menghargai, menghayati, hingga mengamalkan. Pelaksanaan model Problem Based Learning berbasis
Scientific Approach dimaksudkan untuk mendorong siswa menjadi active learner bersama dengan anggota kelompoknya untuk melakukan identifikasi dari masalah yang ada di lingkungan sekitar. Masalah tersebut digunakan untuk mengaitkan rasa keingintahuan serta kemampuan berpikir analitis dan inisiatif atas materi pelajaran.

\section{Hasil Belajar Psikomotor}

Berdasarkan keputusan uji hipotesis, didapatkan bahwa hipotesis nol ditolak, sehingga dapat disimpulkan bahwa model Problem Based Learning berbasis Scientific Approach secara signifikan meningkatkan hasil belajar biologi pada ranah afektif siswa kelas X Di SMA Negeri 2 Banguntapan T.A 2014/2015.

Penggunaan model dan pendekatan pembelajaran tersebut mengakibatkan hasil belajar ranah psikomotor kelas eksperimen lebih tinggi daripada kelas kontrol. Menurut Smith, Ericson dan Lubienski dalam Priadi (2012: 221), penggunaan model Problem Based learning (PBL) memberikan kesempatan siswa untuk mengembangkan kemampuann psikomotornya yang berkaitan dengan keterampilan berkomunikasi, representasi, pemodelan, dan penalaran. Keterampilan tersebut diperoleh melalui kegiatan mengamati, menanya, mencoba, menalar, menyaji, dan mencipta yang kesemuanya merupakan proses-proses yang terdapat pada Scientific Approach (Machin, 2014: 32).

Hasil belajar ranah psikomotor kelas kontrol lebih rendah daripada kelas eksperimen disebabkan karena kelas kontrol hanya menggunakan model Direct Instruction. Model tersebut membuat siswa hanya mencatat dan mendengarkan penjelasan dari guru, sehingga siswa kurang mendapatkan keterampilan dalam proses pembelajaran dan sulit untuk mencapai keberhasilan belajar secara optimal. Model Direct Instruction lebih menekankan pembelajaran yang berpusat pada guru. Selain itu keterampilan psikomotor yang dimunculkan pada pembelajaran dengan menggunakan model ini bersifat sangat sedikit untuk mengembangkan keterampilan psikomotor siswa.

Hasil penelitian ini sesuai dengan penelitian Chunta (2010: 262), yang menyatakan model Problem Based Lerning (PBL) dapat mengembangkan keterampilanketerampilan psikomotor. Selain itu, penelitian yang dilakukan oleh Priadi (2012: 221) yang menjelaskan bahwa model Problem Based Learning (PBL) dapat meningkatkan rerata prestasi psikomotor siswa. Hal tersebut disebabkan karena model Problem Based Learning (PBL) menempatkan siswa sebagai active thinker dalam memperoleh pengetahuan melalui pemecahan masalah dari pengalaman nyata. Pemecahan masalah tersebut dilakukan melalui kegiatan mengamati, menanya, mencoba, menalar, menyaji, dan mencipta yang kesemuanya merupakan proses-proses yang terdapat pada Scientific Approach.

\section{KESIMPULAN}

1. Model Problem Based Learning berbasis Scientific Approach secara signifikan meningkatkan hasil belajar 
biologi pada ranah kognitif siswa kelas X Di SMA Negeri 2 Banguntapan T.A 2014/2015.

2. Model Problem Based Learning berbasis Scientific Approach secara signifikan meningkatkan hasil belajar biologi pada ranahafektif siswa kelas X Di SMA Negeri 2 Banguntapan T.A 2014/2015.

3. Model Problem Based Learning berbasis Scientific Approach secara signifikan meningkatkan hasil belajar biologi pada ranah psikomotorik siswa kelas X Di SMA Negeri 2 Banguntapan T.A 2014/2015.

\section{DAFTAR PUSTAKA}

Af'idah, A.R. Penerapan Model Pembelajaran Berdasarkan Masalah Pada Pembelajaran IPA Terpadu Tema Korosi Besi Untuk Siswa Kelas VII SMP Negeri 1 Bungah Gresik. Jurnal Pendidikan Sains Vol.1(1): 66-70

A'la M. (2010).Quantum Teaching. Yogyakarta: Diva Press

Arnyana, I. B. P. (2005). Pengaruh Penerapan Model PBL Dipandu Strategi Kooperatif Terhadap Kecakapan Berpikir Kritis SMA Pada Mata Pelajaran Biologi.Jurnal Pendidikan dan Pengajaran IKIP Negeri Singaraja No.4 Th.XXXVIII.

Bondan, D. (2011). Problem Based Learning Dan Contoh Implementasinya. Yogyakarta: UNY Press

Chunta, K.S. (2010). Using Problem Based Learning In Staff Development: Strategies For Teaching Registered Nurse And New Graduate Nurse.The Journal Of Continuing Education In 41: 557-564

Fuziah, R. (2013). Pembelajaran Saintifik Elektronika Dasar Berorientasi Pembelajaran Berbasis Masalah. Jurnal INVOTEC Vol.IX(2): 165-178

Harahap, R.F. (2013). Astaga, RI Peringkat ke 64 untuk Pendidikan. (Online) http://kampus.okezone.com/read/ 2013/06/01/373/816065/astaga-ri-peringkat-ke-64-untukpendidikan. 22/11/2014

Hidayati, N. (2014). Pengaruh Penggunan Pendekatan Ilmiah (Scientific Approach) Dalam Pembelajaran Terhadap Hasil Belajar SIswa Kelas XII TITL 1 SMK Negeri 7 Surabaya Pada Standar Kompetensi Mengoperasikan Sistem Kendali Elektromagnetik.Jurnal Pendidikan Teknik ELektro Vol.03 (2): $25-29$

Indriana, D. (2011). Ragam Alat Bantu Media Pengajaran. Yogyakarta: Diva Press

Irwandi. (2012). Pengaruh Pendekatan Kontekstual Dalam Pembelajaran Biologi Melalui Strategi Inkuiri Dan Masyarakat Belajar Pada Siswa Dengan Kemampuan Awal Berbeda Terhadap Hasil Belajar Kognitif Di SMA Negeri Kota Bengkulu.Jurnal Kependidikan Triadik Vol.12(1): 3341

Kemendikbud. (2013). Konsep Pendekatan Scientific. Jakarta: Kemendikbud

Kusumaningtias, A. (2013). Pengaruh Problem Based Learning Dipadu Strategi Numbered Heads Together Terhadap Kemampuan Metakognitif, Berpikir Kritis, Dan Kognitif Biologi.Jurnal Penelitian Kependidikan Vol.23: 33-47

Machin, A. (2014). Implementasi Pendekatan Saintifik, Penanaman Karakter Dan Konservasi Pada Pembelajaran
Materi Pertumbuhan. Jurnal Pendidikan IPA Indonesia Vol.3(1): 28-35

Nurbaiti, S. (2012). Permainan Picoca sebagai Media Pembelajaran Materi Organisasi Kehidupan di SMP.Unnes Journal of Biology Education. 3: 9-16

Nurhidayat, A. (2011). Pengaruh Penerapan Model Pembelajaran Kooperatif Tipe Group Investigation Terhadap Aktivitas dan Penguasaan Konsep Pada Pokok Bahasan Archaebacteria dan Eubancteria Siswa Kelas X SMAN 2 Bantul. Skripsi tidak diterbitkan UIN SUKA.

Paidi. (2003). Penilaian Proses dan Hasil Pembelajaran Biologi. Yogyakarta: UNY Press

Priadi, M.A. (2012). Pembelajaran Biologi Menggunakan Model Problem Based Learning Melalui Metode Eksperimen Laboratorium Dan Lapangan Ditinjau Dari Keberagaman Kemampuan Berpikir Analitis dan Sikap Peduli Lingkungan. Jurnal Inkuiri Vol.1 (3)217-226

Sanjaya, W. (2007). Strategi Pembelajaran Berorientasi Standar Proses Pendidikan. Jakarta: Kencana.

Sujarwanta, A. (2012). Mengkondisikan Pembelajaran IPA Dengan Pendekatan Saintifik. Jurnal Nuansa Kependidikan Vol.16(1): 75-83

Swarabama, L.G. (2013). Pengaruh Model Pembelajaran Sains teknologi Masyarakat Terhadap Pemahaman Konsep Bilogi Dan Keterampilan Berpikir Kreatif Siswa SMA. Jurnal Program Pasca Sarjana Undiksa Vol.3(1): 1-10

Syah, M. (2003). Psikologi Pendidikan dan Pendekatan Baru. Bandung: PT. Remaja Rosdakarya

Syamsuri, I. (2007). Peningkatan Kompetensi Guru Untuk Meningkatkan Minat Siswa Pada Bidang Biologi. Bogor: IPB

Wahyuni. (2009). Motivasi dalam Pembelajaran. Jakarta: Buki Aksara

Wilis, R. (1989). Teori-Teori Belajar. Bandung: Gelora Aksara Pratama 